\title{
Divergent Growth Responses to Warming between Stand-Grown and Open-Grown Trees in a Dryland Montane Forest in Northwestern China
}

\author{
Lei Zhang ${ }^{1,2,3}{ }^{(D}$, Hao Shi ${ }^{4}$, Pengtao Yu ${ }^{1, *}$, Yanhui Wang ${ }^{1}$, Shufen Pan ${ }^{4}$, Bin Wang ${ }^{1}$ and \\ Hanqin Tian $4, *$
}

1 Research Institute of Forest Ecology, Environment and Protection, Chinese Academy of Forestry, Key Laboratory of Forest Ecology and Environment of National Forestry and Grassland Administration, Beijing 100091, China; leizhang_st@rcees.ac.cn (L.Z.); wangyh@caf.ac.cn (Y.W.); wangbinlky@163.com (B.W.)

2 State Key Laboratory of Urban and Regional Ecology, Research Center for Eco-Environmental Sciences, Chinese Academy of Sciences, Beijing 100085, China

3 University of Chinese Academy of Sciences, Beijing 100049, China

4 International Center for Climate and Global Change Research, School of Forestry and Wildlife Sciences, Auburn University, Auburn, AL 36849, USA; hzs0087@auburn.edu (H.S.); panshuf@auburn.edu (S.P.)

* Correspondence: yupt@caf.ac.cn (P.Y.); tianhan@auburn.edu (H.T.); Tel.: +86-10-62889562 (P.Y.); +34-750-1350 (H.T.)

Received: 1 November 2019; Accepted: 7 December 2019; Published: 11 December 2019

\begin{abstract}
Dryland montane forests conserve water for people living in the fluvial plains. The fate of these forests under climate warming is strongly affected by local environmental factors. The question remains of how internal factors contribute to climate change impacts on forest growth in these regions. Here, we investigated tree ring records for similar-aged stand-grown trees and their neighboring open-grown trees at elevation in a dryland montane forest (Picea crassifolia Kom.) in northwestern China. The growth rate of open-grown trees is much higher than their neighboring stand-grown trees across the entire elevation gradient, and the lower the altitude, the greater the difference. Open-grown trees at different elevations showed similar growth patterns, as tree growth at all sites was accelerated over time. In contrast, growth patterns of stand-grown trees were divergent at different altitudes, as growth at high elevations (3100-3300 $\mathrm{m}$ a.s.l.) was accelerated, whereas growth at low elevations (2700-2900 m a.s.1.) became stable after the year 1990. Analysis of growth-climate relationships indicated that warming promoted open-grown tree growth across the entire altitude gradient, and also stand-grown tree growth at high elevations, but negatively affected the growth of stand-grown trees at low elevations. Water scarcity can be exacerbated by competition within forests, inhibiting the warming-induced benefits on tree growth. Moving window correlation analysis suggested the negative effect of warming on tree growth at low elevations was diminished after the late 1990s, as the drought stress was alleviated. Our research shows the divergent growth responses to warming of stand-grown and open-grown trees along elevation. It reveals effects of internal factors in determining tree growth response to warming and holds the potential to aid forest management and ecosystem models in responding to climate change.
\end{abstract}

Keywords: climate warming; dryland forests; tree growth; competition; water limitation; elevation

\section{Introduction}

Dryland (arid and semiarid) forests covered an area of about 1079 Mha worldwide as of 2017 [1], occupying $7.2 \%$ of the total landmass. They not only regulate water supply for humans living in arid and semiarid regions, but also play an important role in global carbon cycles, with their carbon uptake 
rate being similar to those of pine forests in continental Europe and with carbon storage efficiency $60 \%$ higher than the global average [2,3].

Dryland forests are particularly sensitive to climate warming and the associated increase in water stress [4-6]. However, the reports on the climatic effects on tree growth are not always consistent or are even contradictory. Rapid warming was found to accelerate tree growth decline in semiarid forests in inner Asia since approximately 1994 [4] and in some dryland montane forests [6,7]. In contrast, Qi et al. reported an increased forest growth due to warming in the Tianshan Mountains [8]. The disparity between observational evidence raises concerns regarding the factors or mechanisms that determine whether dryland forests can benefit from climate warming.

Previous studies have proposed several mechanisms, including scarce water resources as a primary limit for tree growth of dryland forests, especially at low altitudes; climate warming exacerbating the water availability through increasing land surface evapotranspiration $[9,10]$; and temperature surpassing precipitation to be the most limiting factor at high elevations $[8,11]$. Apart from climatic factors, the internal factors, including forest structure and competition within forests, could also have significant impacts on tree growth (e.g., competition could drive the long-term forest dynamics of North America) [12,13]. Moreover, the trees' sensitivity to competition can vary markedly along environmental gradients [13], which will make the impact of competition more complicated in mountain areas as hydrothermal conditions will change with altitude. However, the majority of studies on tree growth at altitude often ignore the influence of internal factors, which might limit our understanding of the fate of montane forests under climate change [7,14-16].

The trees growing in a forest, also called stand-grown trees, are affected by both climatic factors and competition within the forest. In contrast, open-grown trees, which grow in an open area, are hardly affected by stand density or competition, but are mainly affected by climate [17]. Thus, a comparative study of the two categories at altitude will help to clarify the impact of internal factors on forest responses to warming along environmental gradients.

Here, we conducted a comparative study of stand-grown trees and their neighboring open-grown trees in a Qinghai spruce (Picea crassifolia Kom.) forest in Qilian Mountains, northwest China. The radial growth of trees was investigated along an elevation gradient from $2700 \mathrm{~m}$ to $3300 \mathrm{~m}$ a.s.l. In addition to climate warming, the influence of water deficits on tree growth is the focus of our analysis, as water scarcity is the most limiting factor in drought-prone areas [18,19]. Our main objectives are (1) to investigate the pattern of tree growth along the altitudinal gradient, (2) to clarify tree growth response to warming at different elevations, and (3) to elucidate the role of competition in modulating tree growth under elevated temperature.

\section{Materials and Methods}

\subsection{Study Area}

The study area is located in the northern slope of the central Qilian Mountains $\left(100^{\circ} 17^{\prime} \mathrm{E}, 38^{\circ} 34^{\prime}\right.$ N, Figure 1), northwestern China.

The climate of the study area is arid and semiarid continental. Data from the nearby national meteorological station (Zhangye station, $38^{\circ} 56^{\prime} \mathrm{N}, 100^{\circ} 27^{\prime} \mathrm{E}, 1483.7 \mathrm{~m}$ a.s.l., $45 \mathrm{~km}$ northeast of study site) shows that the annual mean temperature in the region was about $7.5^{\circ} \mathrm{C}$ and the total annual precipitation was $129 \mathrm{~mm}$ over the period 1960-2013. About $84 \%$ of the rainfall occurs in growing season (from May to September). The annual mean temperature increased significantly $(p<0.001)$ from 1960 to 2013 at an approximate rate of $0.34{ }^{\circ} \mathrm{C}$ per decade, and total precipitation rose slightly $(p$ $=0.74$ ). In our study area, the standardized precipitation evapotranspiration index (SPEI), obtained from the Global SPEI database (http://sac.csic.es/spei/database.html) with $0.5^{\circ}$ spatial resolution at a 12-month scale, did not increase significantly $(p=0.09)$ over the whole period (1960-2013), but increased significantly $(p<0.05)$ from the late 1990s onwards (Figure 2). According to an observation (from 1994-2004) at an altitude of $2600 \mathrm{~m}$ in our study area $\left(38^{\circ} 24^{\prime} \mathrm{N}, 100^{\circ} 17^{\prime} \mathrm{E}\right)$, the annual temperature is 
$1.5^{\circ} \mathrm{C}$, the average annual precipitation was $374.1 \mathrm{~mm}$ (varies from 290.2 to $467.8 \mathrm{~mm}$ ), and the annual evaporation was $1043.0 \mathrm{~mm}$. With increasing elevation, annual precipitation generally increased at a rate of $4.95 \%$ per $100 \mathrm{~m}$, but mean annual temperature decreased at a rate of about $0.6{ }^{\circ} \mathrm{C}$ per $100 \mathrm{~m}$ [20].

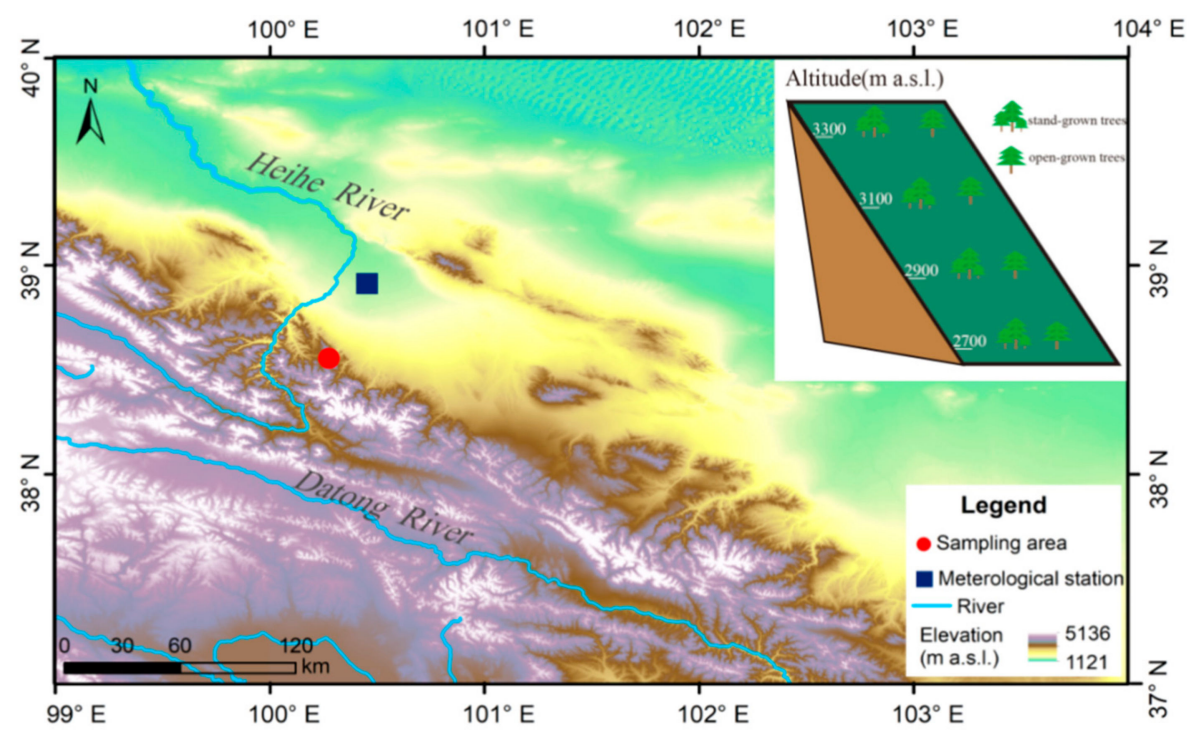

Figure 1. Locations of the sampling area and its nearby meteorological station. The inset in the upper right of the figure is an abridged general view of sampling sites.

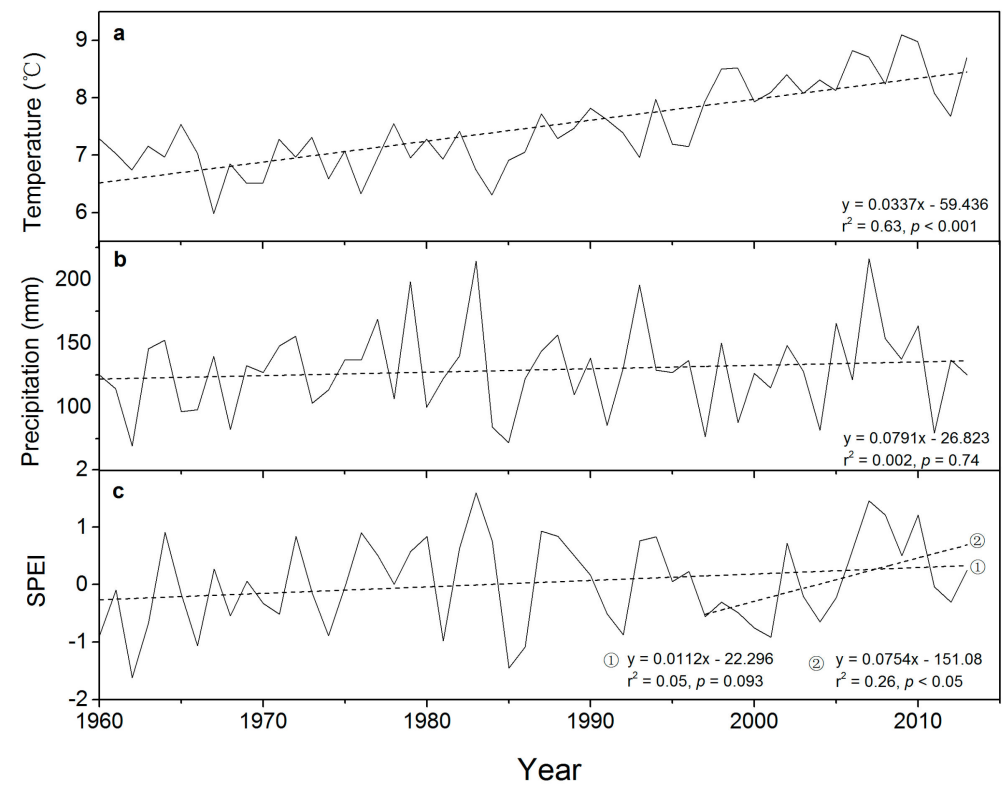

Figure 2. Trends of the annual (a) mean temperature, (b) total precipitation, and (c) standardized precipitation evapotranspiration index (SPEI) in the study area during the period 1960-2013. Dashed lines represent the linear regression, while (1) and (2) indicate the regression line of SPEI for the periods 1960-2013 and 1997-2013, respectively.

The mountain forest is mainly distributed on shady slopes at elevations from 2550 to $3300 \mathrm{~m}$ a.s.l. The upper forest line is at an altitude of about 3300-3400 $\mathrm{m}$ a.s.l. Qinghai spruce (Picea crassifolia Kom.) is the dominant species in the forest. The stand density decreases from 2000-2800 trees.ha ${ }^{-1}$ to only about 300 trees.ha ${ }^{-1}$ with rising elevation [21]. The uneven forest density mainly results from the variations in soil depth, soil texture, and microtopography. Generally, the soil is thicker and the sand content is lower at the low and middle altitudes, but the soil layer is relatively thin and unevenly distributed at high altitudes [22]. Due to its location in the Qilian Mountains National Natural Reserve, 
which was established in the 1980s, the forest has been well protected, and logging and grazing are prohibited. Shrubs are mainly distributed in open forests or nonforest areas, and the main species are Potentilla froticosa, Salix oritrepha, and Rhododendron przewalskii. The dominant understory herbs are Polygonum viviparum, Potentilla glabra, and Kobresia bellardii. Moss is widely distributed under forests and shrubs, and the main species is Abietinella abietina [20].

\subsection{Field Work and Sampling}

Four groups of study sites were set up along the elevation gradient at $2700 \mathrm{~m}$ a.s.l., $2900 \mathrm{~m}$ a.s.l., $3100 \mathrm{~m}$ a.s.l., and $3300 \mathrm{~m}$ a.s.l. All sampling sites were located on shaded or semishaded hillsides of similar slope gradient $\left(25^{\circ}-35^{\circ}\right)$. At each altitude, two categories of average trees, one open-grown and the other stand-grown, were selected for sampling over a distance of $200 \mathrm{~m}$. For example, S2700 is an abbreviation for stand-grown trees and $\mathrm{O} 2700$ is an abbreviation for open-grown trees at an altitude of $2700 \mathrm{~m}$ a.s.l. All sampled trees appeared to be healthy living trees. The open-grown trees were completely discretely distributed, and there was no obstruction between tree canopies. In this area, open-grown trees should be formed not by harvesting, because no stumps were found nearby the sampling sites, but mainly by the micro-topography, as they grew mostly on the top of hills or on slopes with more sand but less soil. In each site, the stand density was recorded by means of sample plot survey, and canopy coverage was visually estimated. For each sampled tree, diameter at breast height (DBH), tree height, crown width, and height were recorded. In order to express density more accurately, a stand density index (SDI), which incorporates the number of trees and their diameter [23], was calculated for each site. The SDI of stand-grown trees ranged from 186.9 in S3300 to 839.0 in S2900. The values of open-grown trees were much lower, ranging from 37.0 in $\mathrm{O} 3100$ to 74.5 in O2700. The crown ratio, which is the ratio of crown height and tree height, was also calculated for each site. At each altitude, crown ratios of open-grown trees were much lower than those of stand-grown trees (Table 1).

Table 1. Basic characteristics of sampling sites and trees.

\begin{tabular}{|c|c|c|c|c|c|c|c|c|c|c|c|c|}
\hline $\begin{array}{l}\text { Altitude } \\
\text { (m a.s.l.) }\end{array}$ & $\begin{array}{l}\text { Soil Depth } \\
\text { (cm) }^{\text {a }}\end{array}$ & $\begin{array}{c}\text { Soil Sand } \\
\text { Content (\%) } \\
\end{array}$ & $\underset{\mathrm{a}, \mathrm{b}}{\mathrm{ANW}}$ & Sites & $\begin{array}{c}\text { Slope } \\
\left({ }^{\circ}\right)\end{array}$ & $\begin{array}{c}\text { Aspect } \\
\left({ }^{\circ}\right)\end{array}$ & $\begin{array}{c}\text { Density } \\
\text { (trees/ha) }\end{array}$ & $\begin{array}{c}\text { Canopy } \\
\text { Coverage (\%) }\end{array}$ & DBH (cm) & SDI & $\begin{array}{l}\text { Height } \\
(\mathrm{m})\end{array}$ & $\begin{array}{c}\text { Crown } \\
\text { Ratio (\%) }\end{array}$ \\
\hline \multirow{2}{*}{2700} & \multirow{2}{*}{80} & \multirow{2}{*}{34} & \multirow{2}{*}{228} & S2700 & 33 & 45 & 2175 & 80 & $11.9 \pm 1.6$ & 660.7 & $8.2 \pm 2.6$ & $35.7 \pm 20.1$ \\
\hline & & & & $\mathrm{O} 2700$ & 25 & 15 & 75 & 25 & $24.9 \pm 3.5$ & 74.5 & $12.2 \pm 3.5$ & $70.2 \pm 15.1$ \\
\hline \multirow{2}{*}{2900} & \multirow{2}{*}{60} & \multirow{2}{*}{44} & \multirow{2}{*}{377} & S2900 & 32 & 24 & 2725 & 90 & $12.0 \pm 0.9$ & 839.0 & $8.6 \pm 2.8$ & $34.0 \pm 11.5$ \\
\hline & & & & O2900 & 35 & 20 & 100 & 25 & $19.9 \pm 3.6$ & 69.5 & $11.5 \pm 2.6$ & $64.5 \pm 16.7$ \\
\hline \multirow{2}{*}{3100} & \multirow{2}{*}{50} & \multirow{2}{*}{47} & \multirow{2}{*}{587} & S3100 & 32 & 25 & 1150 & 67 & $15.4 \pm 1.2$ & 528.4 & $8.1 \pm 1.9$ & $50.2 \pm 16.4$ \\
\hline & & & & O3100 & 35 & 22 & 75 & 20 & $16.1 \pm 4.1$ & 37.0 & $10.5 \pm 2.1$ & $70.6 \pm 15.1$ \\
\hline \multirow{2}{*}{3300} & \multirow{2}{*}{50} & \multirow{2}{*}{58} & \multirow{2}{*}{422} & S3300 & 35 & 32 & 375 & 25 & $16.2 \pm 1.5$ & 186.9 & $6.0 \pm 1.6$ & $67.7 \pm 12.3$ \\
\hline & & & & O3300 & 32 & 30 & 75 & 20 & $17.9 \pm 1.9$ & 43.8 & $9.6 \pm 1.7$ & $75.7 \pm 11.0$ \\
\hline
\end{tabular}

${ }^{a}$ Refers to F. Sun et al., 2015 [22]. Soil thicknesses were investigated by soil profile and soil drill methods; there were about 10 sampling points at each altitude. Soil sand content was measured with sieves. ${ }^{\mathrm{b}}$ ANW: accumulated value of natural soil moisture content (unitless). Soil moisture was measured by $\mathrm{H} 21$ and U30 monitoring systems. Note: $\mathrm{DBH}=$ diameter at breast height; $\mathrm{SDI}=$ stand density index. Data is expressed as the mean \pm standard deviation. In sites column, $\mathrm{S}$ refers to stand-grown and $\mathrm{O}$ refers to open-grown trees, with corresponding numbers representing the altitude in $\mathrm{m}$ a.s.l.

Two or three cores were taken from each tree at a height of $1.3 \mathrm{~m}$. Tree cores were then dried, mounted in wooden stripes, and sanded with coarse to fine sandpapers. To ensure the integrity of the time series of tree rings, cores failing to contain rings from bark to pith were discarded. Ring width was measured to an accuracy of $0.01 \mathrm{~mm}$ using LINTAB, a tree-ring analysis system developed by Rinntech Corp., Germany. The quality of all measurement time series was checked using the COFECHA, a computer program written by Richard L. Holmels to assess the quality of crossdating and measurement accuracy of tree-ring series [24]. Then, tree age was obtained by counting the number of rings from bark to pith. To exclude the effects of age, only trees of the same age class (40-80 years) were selected for analysis. As a result, a total of 273 cores of 134 trees were taken, but only 168 cores of 112 trees were used for analysis (Table S1). The mean sensitivities (MS) were calculated to assess year-to-year variability of tree ring width, and the values ranged from 0.12 to 0.376 , showing a decreasing trend 
with increasing altitude. The expressed population signals (EPS) ranged from 0.912 to 0.995 , indicating that the number of trees is sufficient to represent the entire population $[25,26]$. The year when the subsample signal strength (SSS) reaches 0.85 varies among sites, but in all cases this occurs after 1964, indicating the chronologies at all sites are statistically reliable over the period 1964-2013 [25]. Detailed information on the sampling was summarized in Table 2.

Table 2. Summary for the characteristics of site-specific chronologies.

\begin{tabular}{ccccccc}
\hline $\begin{array}{c}\text { Altitudes } \\
\text { (m a.s.1.) }\end{array}$ & Sites & $\begin{array}{c}\text { No. of } \\
\text { Cores/Trees }\end{array}$ & $\begin{array}{c}\text { Average Age (Age } \\
\text { Range) }\end{array}$ & MS & EPS & SSS $>\mathbf{0 . 8 5}$ \\
\hline \multirow{2}{*}{2700} & $\mathrm{~S} 2700$ & $45 / 30$ & $62(51-70)$ & 0.376 & 0.989 & $1945-2013$ \\
& $\mathrm{O} 2700$ & $4 / 3$ & $62(58-65)$ & 0.336 & 0.939 & $1949-2013$ \\
\hline \multirow{2}{*}{2900} & $\mathrm{~S} 2900$ & $73 / 47$ & $62(52-74)$ & 0.319 & 0.995 & $1945-2013$ \\
& $\mathrm{O} 2900$ & $3 / 3$ & $59(54-63)$ & 0.295 & 0.912 & $1954-2013$ \\
\hline \multirow{2}{*}{3100} & $\mathrm{~S} 3100$ & $25 / 16$ & $59(40-80)$ & 0.165 & 0.982 & $1951-2013$ \\
& $\mathrm{O} 3100$ & $4 / 3$ & $59(52-66)$ & 0.12 & 0.954 & $1950-2013$ \\
\hline \multirow{2}{*}{3300} & $\mathrm{~S} 3300$ & $10 / 7$ & $55(41-80)$ & 0.137 & 0.932 & $1964-2013$ \\
& $\mathrm{O} 3300$ & $4 / 3$ & $66(49-79)$ & 0.151 & 0.957 & $1940-2013$ \\
\hline
\end{tabular}

Note: MS = mean sensitivities; EPS = expressed population signals; SSS = subsample signal strength.

\subsection{Development of Basal Area Increment (BAI)}

To quantify the speed and trend of tree growth, the basal area increment (BAI) was calculated as in previous studies $[8,14,15]$. BAI was calculated following $\mathrm{BAI}=\pi\left(R_{n}^{2}-R_{n-1}^{2}\right)$, where $R_{n}$ is the stem radius in the year $n$, and $R_{n-1}$ is the stem radius in the year $n-1$. The BAI chronologies were calculated as the average of the BAI for each year of all trees at each sampling site.

\subsection{Climate Data}

There were no long-term meteorological observations at high altitudes in our study area. Therefore, monthly climate data from the nearby national meteorological station (Zhangye station, $38^{\circ} 56^{\prime} \mathrm{N}^{\prime}$ $100^{\circ} 27^{\prime} \mathrm{E}, 1483.7 \mathrm{~m}$ a.s.1.) were obtained for growth-climate relationship analysis. In order to assess the applicability of these data, we compared the annual precipitation from Zhangye station to ten-year observations (from 1994-2003) at $2700 \mathrm{~m}$ a.s.l. in the study area [27], and a common temporal pattern was found $(\mathrm{r}=0.84, p<0.001)$. Additionally, the nearest Climate Research Unit (CRU) grid data $\left(38^{\circ} 45^{\prime} \mathrm{N}, 100^{\circ} 25^{\prime} \mathrm{E}\right)$ with $0.5^{\circ}$ spatial resolution were obtained from the Climate Research Unit (CRU, http://www.cru.uea.ac.uk/) [28] to compare with records from Zhangye station. The mean annual temperature of the two data sets correlated significantly $(\mathrm{r}=0.70, p<0.001)$, and annual precipitation was the same $(r=0.77, p<0.001)$ (Figure S1). In addition, climate variables from CRU datasets were used for growth-climate analysis at the same time. To assess the impact of water scarcity on tree growth, a drought index, namely standardized precipitation evapotranspiration index (SPEI), was obtained from the Global SPEI database with $0.5^{\circ}$ spatial resolution at a 12 -month scale.

\subsection{Assessment of Release Effects}

Release effects, which are caused by logging or other disturbances, could trigger a growth pulse in trees [23]. Therefore, it is necessary to assess the release effect before analyzing the growth-climate relationship. Here, we introduce the percentage growth change (GC\%) to the study, which has been proven to be effective in assessing the growth release pattern and possible disturbance history of both stand-grown and open-grown trees [29-31]. The GC\% was calculated for each site according to GC $\%=$ $\left(M_{2}-M_{1}\right) / M_{1}$, where GC\% is percentage growth release between preceding and subsequent 10-year means, and $\mathrm{M}_{1}$ and $\mathrm{M}_{2}$ are the preceding and subsequent 10-year ring-width means, respectively. Values of GC $\% \geq 50 \%$ and $\geq 100 \%$ were set to define a minor growth release and a major release, respectively. 


\subsection{Statistical Analysis}

The BAI chronologies for both stand-grown and open-grown trees were smoothed using 15-year moving averages, in order to highlight the growth trends while retaining their variability. To examine the degree of similarity in growth patterns, correlation matrices of the BAI chronologies were created over the common period 1964-2013. The ratio of BAI values of open-grown trees and the nearby stand-grown trees for each year was calculated over the same period to assess the growth difference.

In order to determined growth-climate relationships, Pearson's correlation and linear regression analyses were performed between BAI chronologies and the monthly or seasonal climate factors (including mean temperature, total precipitation, and SPEI) over the period 1964-2013. Moreover, to test the temporal stability of growth-climate relationships, we correlated BAI chronologies with seasonal mean temperature using a 25 -year moving window.

The above analyses were all performed over the period 1964-2013, because: (1) according to assessment of GC\%, growths of stand- and open-grown trees were less affected by release effect after 1964; and (2) the subsample signal strength (SSS) of each site reached the threshold value of 0.85 during 1964-2013, indicating that the chronologies are most reliable for growth-climate analysis [25].

\section{Results}

\subsection{Growth and Release Patterns}

Figure 3 shows different growth patterns for the stand-grown and open-grown trees. For stand-grown trees, annual BAI across all elevations increased at a similar rate before approximately 1970. Then, tree growth at different elevations showed divergent trends, with higher growth rate at higher elevations. Particularly, tree growth at the highest elevation (S3300) was greatly accelerated, whereas growth in S2700 and S2900 became stable after approximately 1990. For open-grown trees, growth at all sites was accelerated throughout the whole period, but at different rates. Starting in the mid-1970s, the trees growing at the lowest altitude (O2700) showed the highest growth rate, followed by O2900, whereas trees at higher altitudes grew at lower rates.

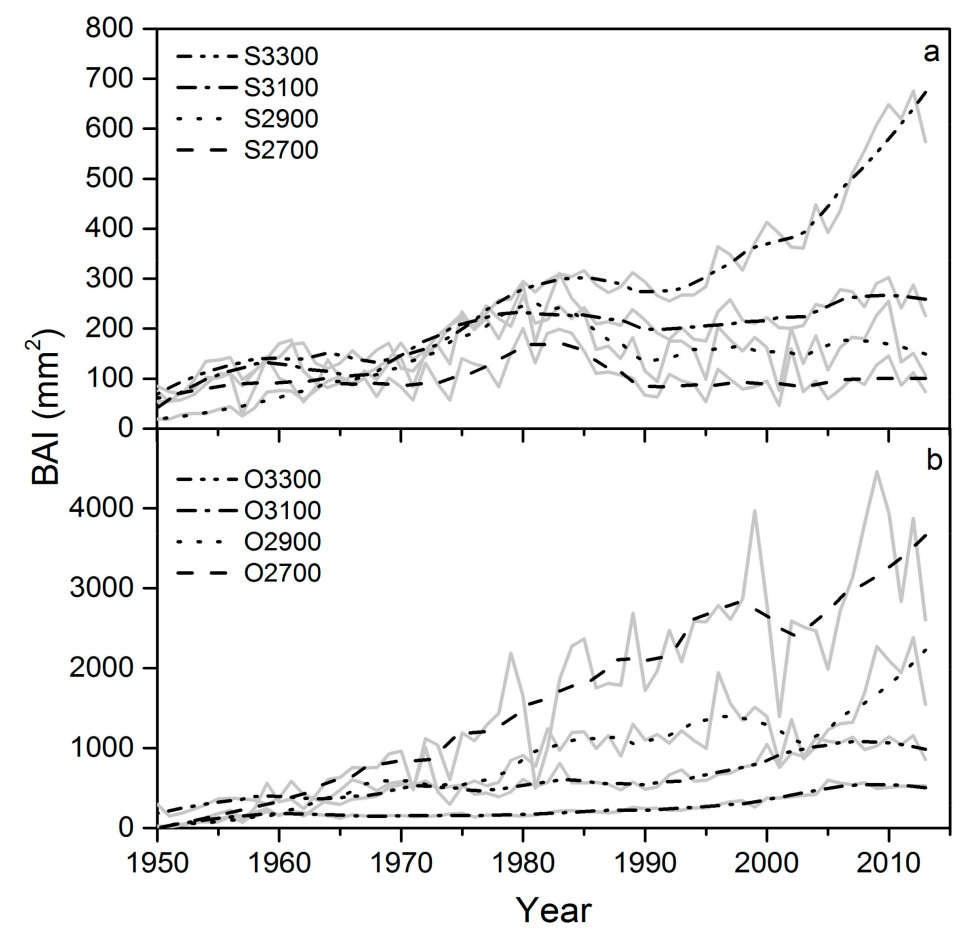

Figure 3. BAI chronologies of (a) stand-grown and (b) open-grown trees along the elevation gradient. Gray lines indicate the yearly measurements and black dashed lines indicate the 15-year moving average. 
For stand-grown trees, GC\% of at the four sites showed a similar temporal trend with all values being lower than 50\%, except for the GC\% in S2700, which was higher than $100 \%$ before 1960 . For open-grown trees, GC\% values greater than $100 \%$ mainly occurred before 1964 . After 1964, only the GC\% in O3300 in 1966 was higher than 100\%, while other values were less than 50\% (Figure 4). This suggests that the growths of stand- and open-grown trees are less affected by release effect, especially during the period after 1964 [29,30].

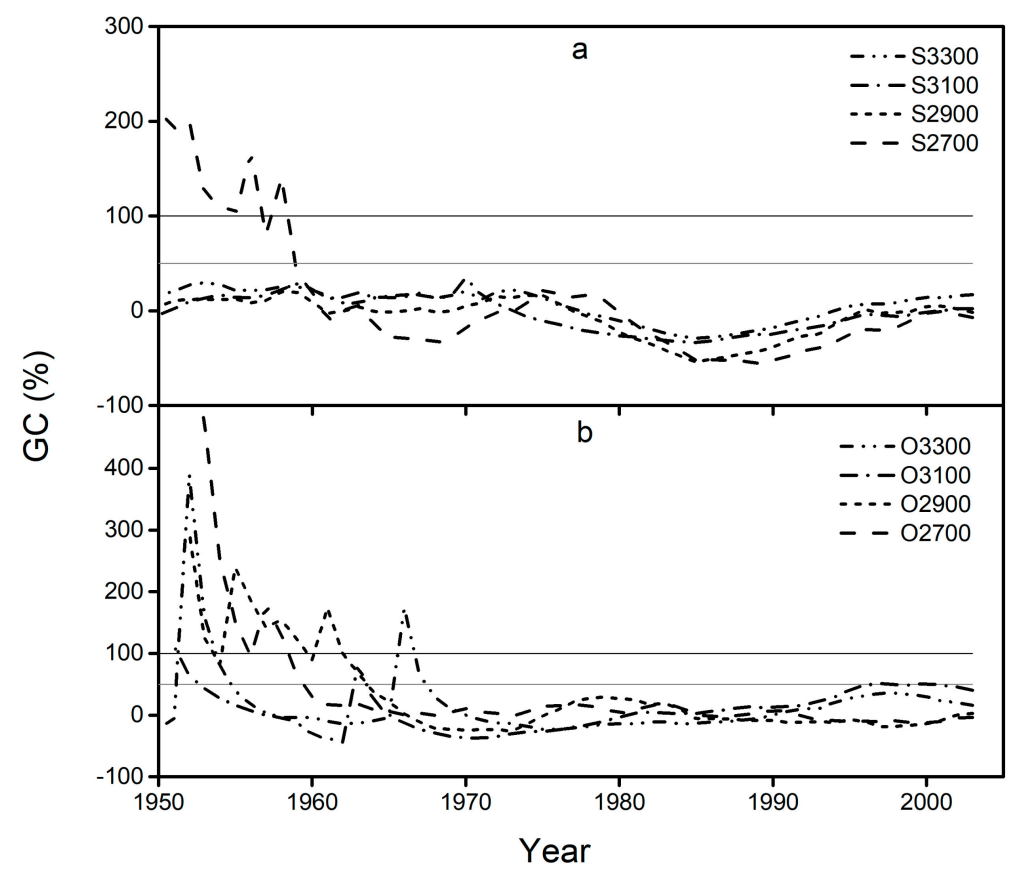

Figure 4. Percentage growth change (\%GC) of (a) stand-grown and (b) open-grown trees. Major (100\%) and minor $(50 \%)$ growth releases are indicated by the black and gray lines, respectively.

Table 3 shows that correlations between the chronologies of stand-grown trees from three different elevations (S2700 and S2900, S2900 and S3100, S3100 and S3300) were significant $(p<0.01)$. However, there were no significant correlations between the highest altitude (S3300) and either of the two lower altitudes (S2700 and S2900). In contrast, BAI chronologies of the open-grown trees at different elevations were all significantly correlated $(p<0.05)$ with each other, implying that the growth trends of open-grown trees remained consistent across the entire altitude gradient. Correlation coefficients of stand-grown and open-grown trees from the same altitude were significant $(p<0.01)$ at $3100 \mathrm{~m}$ a.s.l. and $3300 \mathrm{~m}$ a.s.l., but not significant at $2700 \mathrm{~m}$ a.s.l. $(p=0.018)$ and $2900 \mathrm{~m}$ a.s.l. $(p=0.275)$, indicating that the growth trends of stand-grown trees and open-grown trees are different at low elevations.

Table 3. Correlation matrices of BAI chronologies of (a) stand-grown trees, (b) open-grown trees, and (c) stand-grown and open-grown trees from the same altitude for the common period 1964-2013.

Double asterisks indicates significance at 0.01 levels.

\begin{tabular}{|c|c|c|c|c|c|c|c|c|c|c|c|c|c|c|}
\hline (a) & S2700 & S2900 & S3100 & S3300 & (b) & $\mathrm{O} 2700$ & O2900 & O3100 & O3300 & (c) & S2700 & S2900 & S3100 & S3300 \\
\hline S2700 & 1 & $0.833^{* *}$ & 0.229 & 0.009 & $\mathrm{O} 2700$ & 1 & 0.882 ** & $0.745^{* *}$ & $0.763^{* *}$ & O2700 & 0.018 & & & \\
\hline S2900 & & 1 & $0.594^{* *}$ & 0.2 & $\mathrm{O} 2900$ & & 1 & $0.763^{* *}$ & $0.741^{* *}$ & O2900 & & 0.275 & & \\
\hline S3100 & & & 1 & $0.75^{* *}$ & O3100 & & & 1 & 0.913 ** & O3100 & & & $0.624^{* *}$ & \\
\hline
\end{tabular}

Figure 5 shows that the growth rate of open-grown trees was higher than that of stand-grown trees from the same altitude, and the difference showed a decreasing trend with elevation. The multiyear average BAI values of open-grown trees was more than 17 times larger than that of stand-grown trees at the altitude of $2700 \mathrm{~m}$ a.s.l. but less than 3 times at the altitude of $3300 \mathrm{~m}$ a.s.l. 


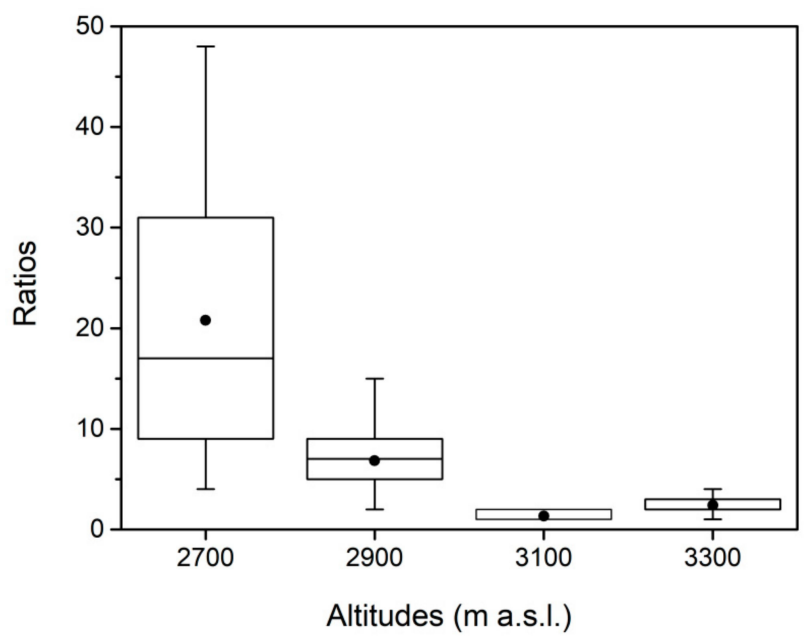

Figure 5. Ratios of annual BAI values between open-grown trees and their neighboring stand-grown trees at each elevation over the common period 1964-2013.

\subsection{Growth-Climate Relationship}

For stand-grown trees, growth-climate relationships were different among sites (Figure 6a,c,e). BAI chronology-temperature correlations were mainly positive at high elevations (S3100 and S3300) but negative at low elevations (S2700 and S2900). For the highest elevation (S3300), significant positive correlations $(p<0.05)$ occurred in almost all months from the previous May to the current October (except the previous December and current January). In S3100, significant correlations $(p<0.05)$ occurred in May, June, September, and October of the previous year, and May to October of the current year. For the two low elevations, the negative correlations were stronger in S2700 than that in S2900. In S2700, the correlation of BAI chronologies with mean temperature was significantly negative $(p<0.05)$ in the previous August and current July. When calculating the correlations between tree growth and mean temperature in the growing season (May to September), the strongest positive correlation occurred in S3300 $(p<0.01)$, and the strongest negative correlation occurred in S2700. Correlations between precipitation and growth of stand-grown trees were mainly positive at low elevations, reaching significant levels $(p<0.05)$ in the previous August and September in S2700 and S2900, and in the current May in S2700. During the growing season, the positive correlations of BAI chronologies and precipitation reached significant levels $(p<0.05)$ at both S2700 and S2900. However, the correlation coefficients were much lower in S3100 and S3300. Similar relationships were found when using CRU data for analysis (Figure S2a,c). Almost all monthly SPEI values (except in previous June-July) promoted tree growth, especially at low elevations, as significant correlations $(p<0.05)$ were found in the current May-August period in S2700 and S2900. During the growing season, SPEI had a stronger promoting effect at lower altitudes, with the highest value of 0.525 occurring in S2700. Linear regression analysis shows that over $25 \%$ of BAI variation was explained by SPEI in S2700 and S2900, but the BAI variation was mainly explained by temperature in S3100 and S3300, with the adjusted r-square values ranging from $23 \%$ to $68 \%$ (Figure S3).

For open-grown trees, the growth-temperature patterns were relatively consistent across the altitude gradient (Figure $6 \mathrm{~b}, \mathrm{~d}, \mathrm{f})$. BAI chronologies at all four altitudes were positively $(p<0.05)$ correlated with temperature in almost all months, except the current January. Strong positive $(p$ $<0.05)$ correlations were found between growth and mean temperature in growing season at all sites. Similar relationships were found when CRU data were used for analysis (Figure S2b,d). Linear regression analysis showed that temperature explained most of the BAI variation across the entire altitude gradient, with adjusted r-square values ranging from $42 \%$ to $76 \%$ (Figure S4). In contrast, tree growth was poorly correlated with precipitation and SPEI across all altitude gradients. 


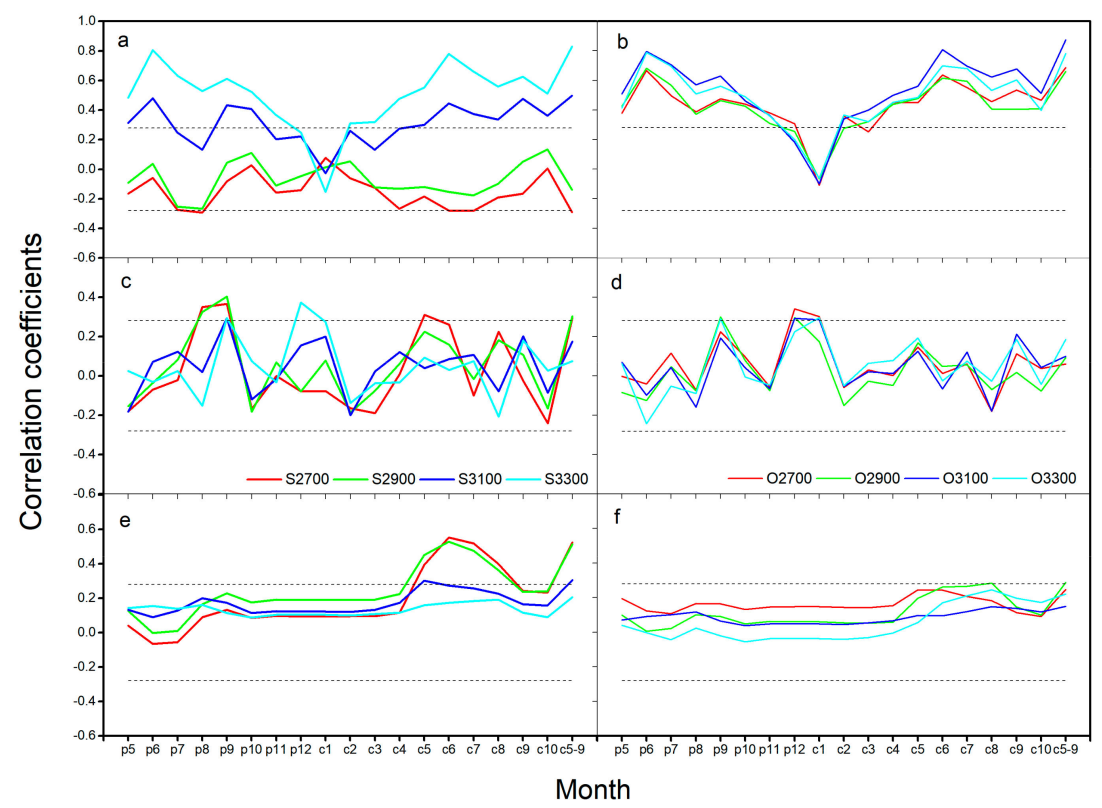

Figure 6. Correlation coefficients of BAI chronologies for $(\mathbf{a}, \mathbf{b})$ temperature, $(\mathbf{c}, \mathbf{b})$ precipitation, and $(\mathbf{e}, \mathbf{f})$ standardized precipitation evapotranspiration index (SPEI) for $(\mathbf{a}, \mathbf{c}, \mathbf{e})$ stand-grown and $(\mathbf{b}, \mathbf{d}, \mathbf{f})$ open-grown trees at different elevations during the period 1964-2013. Dashed lines indicate a significance level of 0.05 . The $\mathrm{p}$ indicates the climate variables of the previous year, $\mathrm{c}$ indicates the climate variables of the current year, and c5-9 indicates the current growing season (May to September).

Moving window correlation analysis (Figure 7) showed that the relationship of growth and temperature for stand-grown trees in S3300 and S3100 increased positively, and reached a significant level $(p<0.05)$ at the end of the analysis period. In S2700 and S2900, tree growth showed an increasing negative correlation with temperature until the 1982-2006 period, when the negative correlation decreased. For open-grown trees, temporal patterns of moving correlation of growth and temperature were relatively consistent across the entire altitude gradient, and all of the correlations increased to a positively significant level $(p<0.05)$ at the end of the period 1964-2013. When using CRU data for the moving analysis, the same trend was found (Figure S5).

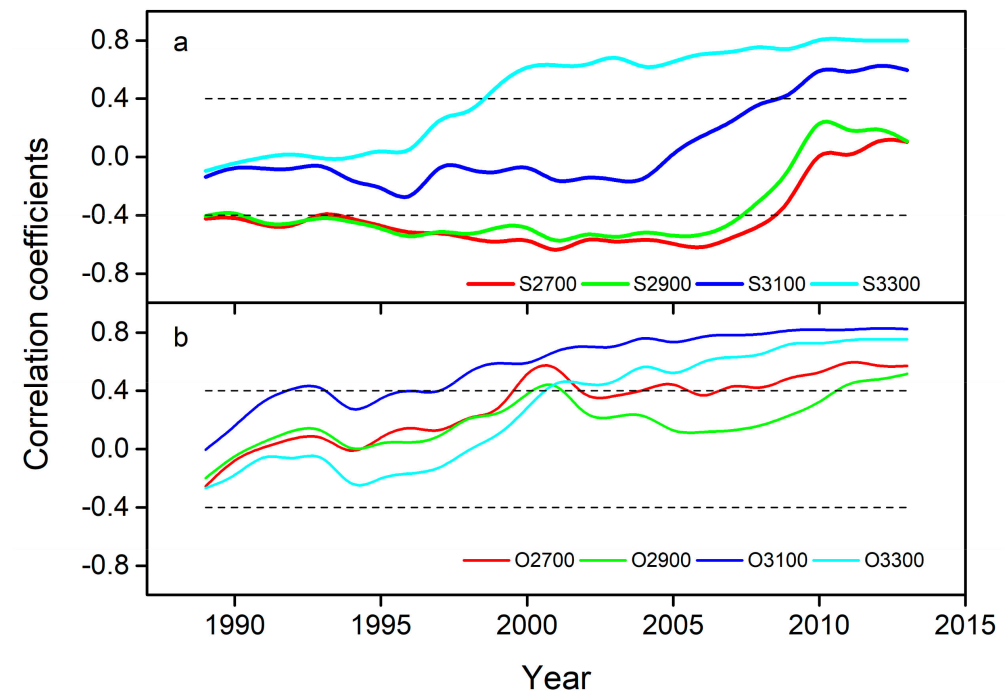

Figure 7. Moving correlations (25-year window) between BAI chronologies and growing season (May to September) mean temperatures for (a) stand-grown and (b) open-grown trees from 1964 to 2013. Dashed lines indicate a significant level of 0.05 . 


\section{Discussion}

Tree growth is generally thought to decrease with increasing elevation [32-34], primarily due to the harsh climatic conditions at high elevations [35]. The mean annual temperature may be only 7-8 ${ }^{\circ} \mathrm{C}$ in global temperate treeline zones [36]. Low temperatures at high elevations can lead to insufficient carbon assimilation, thus inhibiting cell replication, division, and differentiation [35,37]. Therefore, an accelerated growth of stand-grown trees was found with increasing temperature in S3300 and S3100 (Figures 3 and 6, and Figure S3). Studies have shown that the release effect can also lead to faster tree growth $[23,29]$, but in our study, the accelerated growth is likely not caused by release, because GC\% values for S3300 and S3100 were less than 50\% in the whole study period (Figure 4).

However, the warming effects on growth of stand-grown trees changed from positive to negative with decreasing elevation (Figures 3 and 6). This is inconsistent with the direct effect of increasing temperature on tree growth, because temperature increase before this at the optimum temperature (around $15-20^{\circ} \mathrm{C}$ ) for net photosynthesis should enhance tree growth [38,39]. However. The mean annual temperature in our study area (from approximately -6.3 to $2{ }^{\circ} \mathrm{C}$ ) [20] remained far lower than the optimum temperature for spruce growth.

This unexpected growth-temperature pattern could be partly attributed to the impact of water scarcity. In S2700 and S2900, tree growth was positively correlated $(p<0.05)$ with SPEI and precipitation, and more than $25 \%$ of BAI variation was explained by SPEI (Figure $6 c, e$ and Figure S3). This suggests water deficit inhibits tree growth and might weaken the benefit of climate warming especially in lower elevations, as also found in the Mediterranean regions, Central European, and southern Tibetan Plantae $[14,16,33]$. Higher MS values at low altitudes (Table 2) also suggest the water limit, as the mean sensitivity of tree rings are usually higher in arid sites than in wet sites [26]. Interestingly, drought stress in the study area was alleviated since the late 1990s, as shown in the interannual variation of SPEI (Figure 2c). At the same time, correlations between growth and temperature in S2700 and S2900 gradually changed to positive (Figure 7a). The simultaneous changes further suggest that the temperature promotion effects depend on water condition for stand-grown trees at low altitudes. But for open-grown trees, the relationships of tree growth and SPEI (and also precipitation) were much weaker (Figure $6 \mathrm{~d}, \mathrm{f}$ ). However, growth-temperature correlations were strong (Figure $6 \mathrm{~b}$ ) and $42 \%-76 \%$ of BAI variation was explained by temperature (Figure S4), suggesting that growth of open-grown trees is mainly controlled by temperature rather than drought, even at low altitudes.

The above opposite relationships of growth and temperature between stand-grown and open-grown trees could be further explained by internal factors. The SDI values were much higher for stand-grown trees (Table 1), which could lead to insufficient water supply for each individual tree and intense competition between trees $[23,40]$. In order to avoid excessive water loss, trees subjected to high competition often present lower sap flow density, stomatal conductance, and photosynthetic rates [41,42], resulting in slower growth and weaker response to warming. The results could also be confirmed by an observation in eastern Qilian Mountains, which found that stand-grown trees growing in dense forest (with a density of 1300-2000 trees $\cdot \mathrm{ha}^{-1}$ ) declined in growth with more frequent deaths, while those growing in sparse forest (with a density of 400-600 trees:ha ${ }^{-1}$ ) maintained stable growth under climate warming conditions [43]. In Eastern Europe, similar changes in climate-growth relationships resulting from increased density and competition were found in Norway spruce forests. In that area, as competition increased, tree growth at low altitudes showed a higher negative correlation with temperature and a higher positive correlation with precipitation [44]. The differences in light intensity could be an additional factor. Open-grown trees, which grow in an open area with lower canopy coverage and which have larger crown ratios (Table 1) can capture more light, which could promote tree growth, leading them to then show a positive response to temperature rise. However, further analysis cannot be carried out here due to lack of data.

The effect of competition might interrelate with water availability. In S2700, tree growth rate and its response to warming was more strongly inhibited than in S2900 (Figure 4), even if the SDI in S2700 is lower than S2900 (Table 1). It is noted that competition intensity tends to increase with decreasing 
resource availability $[12,45]$. This may result in stronger competition amongst stand-grown trees at lower elevation, where there is lower soil moisture (Table 1). In contrast, at high elevations with higher moisture content and lower SDI (Table 1), even if competition did slow down tree growth (Figure 5), it did not reach a threshold that would reverse the response of tree growth to warming (Figures 3 and 6). The above helps explain why warming has slowed drown tree growth in some areas with severe water deficits, but promoted the growth of alpine forests in drylands [6-8,11]. However, the benefits of climate warming on tree growth at high elevations may also be diminished with increasing stand density, as has been found for an alpine treeline in the southeastern Tibetan Plateau [46]. It is expected that trees already suffering from competition will be more vulnerable to climate variability [47].

Our results show that the stand density and competition within forests can largely affect growth rate and modulate the response to climate warming (Figures 3 and 6, Table 3). Thus, we can address drought related to climate warming by managing forest structures. In fact, a series of studies in the Mediterranean and North America have proven that thinning is an effective measure, as water uptake capacity and water use efficiency are enhanced after thinning, accompanied by the acceleration of tree growth $[42,48,49]$. The difference in ecosystem resilience to warming is another concern. In our study area, higher growth rates and more positive responses were found at high altitude with lower stand density and higher water availability, but a negative response was found at low altitude. This indicates that sparse forests at high altitude might have a higher resilience to climate warming than dense forests at low altitude. Similarly, a previous study showed that missing ring and forest mortality take place more frequently in dense forests than in sparse forests in central Qilian Mountains [50]. This suggests that density management will help improve forest resilience to climate warming.

Because water availability and stand density may vary with elevation, forests at different elevations should be treated separately. In our region, the forests most in need of thinning are mainly grown below $2900 \mathrm{~m}$ a.s.l. where tree growth has been strongly inhibited and responds negatively to warming (Figures $3 \mathrm{a}$ and $6 \mathrm{a}$ ). Over the past decades, the negative correlation of tree growth and temperature at low elevations has decreased due to mitigation of drought stress (Figures 2c and 7a), so we can expect that the elevational threshold might decrease in the future.

The internal factors, such as forest density and competition, have been coupled in growth models at individual or stand levels [51,52]. However, land surface ecosystem models, which can simulate the biosphere-atmosphere interactions at large spatial scales and assess regional and global carbon budgets [53-55], still lack descriptions of these factors. This makes it difficult to accurately predict ecosystem responses to climate change at regional and global scales [56-58]. A recent simulation study showed that the net primary production, carbon use efficiency (the ratio of net to gross primary productivity), and carbon woody stocks of thinned forests are higher than unthinned forests under climate warming [59], suggesting that competition could modify the components and processes of carbon dynamics at the ecosystem scale. Considering the carbon uptake rate of semiarid forests is similar to those of pine forests in continental Europe, and that their carbon storage efficiency is $60 \%$ higher than the global average [2,3], the effect of competition in the dryland forests could significantly contribute to the estimation of global carbon cycles.

In the future, global temperatures are more likely to continue to rise and accompany the expansion of drylands [60]. This may further enhance the importance of competition in predicting the fate of dryland forests. Therefore, land surface models should describe the internal factors in more detail, for example by incorporating stand density and basal area as variables into the model to improve the accuracy of simulation.

\section{Conclusions}

Our study has found that in the dryland mountain forest of northwestern China, open-grown trees across the entire elevation gradient benefit from warming, leading to faster growth. In contrast, stand-grown trees grow more slowly and benefit from warming only at high elevations. Competition and consequent water shortage inhibit tree growth and weaken the benefits of warming, and could 
even reverse the effect of warming from positive to negative, especially at low elevations with less precipitation and higher stand density. With this in mind, effective measures such as thinning at low elevations should be highlighted in future management plans for dryland forests. Additionally, we suggest the role of internal factors, such as stand density and competition, should be investigated in predicting forest fate and global carbon cycles in the future.

Supplementary Materials: The following are available online at http://www.mdpi.com/1999-4907/10/12/1133/s1. Figure S1. Comparison of climate data from (a) Zhangye station with (b) the CRU dataset and (c) observations by Wang et al., 2006. Figure S2. Correlation coefficients of BAI chronologies with $(a, b)$ temperature and $(c, b)$ precipitation from the CRU dataset (CRU TS 3.10, http://www.cru.uea.ac.uk/) for (a,c) stand-grown and (b,d) open-grown trees at different altitudes. Dashed lines indicate a significant level of 0.05, and c5-9 indicates the current growing season (May to September). Figure S3. Relationships between BAI chronologies and SPEI and mean temperature (Tem) in the growing season (May to September) for stand-grown trees at different altitudes. Figure S4. Relationships between BAI chronologies and SPEI and mean temperature (Tem) in the growing season (May to September) for open-grown trees at different altitudes. Figure S5. Moving correlations (25-year window) between BAI chronologies and the growing season (May to September) mean temperature form the CRU dataset (CRU TS 3.10, http://www.cru.uea.ac.uk/) for (a) stand-grown and (b) open-grown trees from 1964 to 2013. Dashed lines indicate a significance level of 0.05 . Table S1. Statistics on the numbers of cores/tree were taken and used at different sampling sites.

Author Contributions: Conceptualization, P.Y., Y.W., and L.Z.; investigation, L.Z. and B.W.; formal analysis, L.Z. and H.S.; original draft preparation, L.Z.; review and editing, L.Z., H.S., P.Y., Y.W., S.P., and H.T.

Funding: This research was funded by National Key R\&D Program of China (2016YFC0501702, 2017YFA0604702), Natural Science Foundation of China (41671025, 91425301), CAS STS Program (KFJ-STS-ZDTP-010-05), and SKLURE Grant (SKLURE 2017-1-6).

Acknowledgments: We thank Shunli Wang, Xiande Liu, Xuelong Zhang, Ming Jin, and other staff of the Academy of Water Resource Conservation Forests of Qilian Mountains in Gansu Province for their assistance in the field work.

Conflicts of Interest: The authors declare no conflict of interest.

\section{References}

1. Bastin, J.F.; Berrahmouni, N.; Grainger, A.; Maniatis, D.; Mollicone, D.; Moore, R.; Patriarca, C.; Picard, N.; Sparrow, B.; Abraham, E.M. The extent of forest in dryland biomes. Science 2017, 356, 635-638. [CrossRef] [PubMed]

2. Rotenberg, E.; Yakir, D. Contribution of semi-arid forests to the climate system. Science 2010, 327, 451-454. [CrossRef] [PubMed]

3. Schimel, D.S. Drylands in the earth system. Science 2010, 327, 418-419. [CrossRef] [PubMed]

4. Liu, H.; Park Williams, A.; Allen, C.D.; Guo, D.; Wu, X.; Anenkhonov, O.A.; Liang, E.; Sandanov, D.V.; Yin, Y.; Qi, Z.; et al. Rapid warming accelerates tree growth decline in semi-arid forests of inner Asia. Glob. Chang. Biol. 2013, 19, 2500-2510. [CrossRef]

5. Poulter, B.; Pederson, N.; Liu, H.; Zhu, Z.; D’Arrigo, R.; Ciais, P.; Davi, N.; Frank, D.; Leland, C.; Myneni, R.; et al. Recent trends in inner Asian forest dynamics to temperature and precipitation indicate high sensitivity to climate change. Agric. Meteorol. 2013, 178, 31-45. [CrossRef]

6. Liang, E.; Leuschner, C.; Dulamsuren, C.; Wagner, B.; Hauck, M. Global warming-related tree growth decline and mortality on the north-eastern Tibetan plateau. Clim. Chang. 2015, 134, 163-176. [CrossRef]

7. Jiao, L.; Jiang, Y.; Wang, M.; Kang, X.; Zhang, W.; Zhang, L.; Zhao, S. Responses to climate change in radial growth of Picea schrenkiana along elevations of the eastern Tianshan mountains, Northwest China. Dendrochronologia 2016, 40, 117-127. [CrossRef]

8. Qi, Z.; Liu, H.; Wu, X.; Hao, Q. Climate-driven speedup of alpine treeline forest growth in the Tianshan mountains, northwestern china. Glob. Chang. Biol. 2015, 21, 816-826. [CrossRef]

9. Bonan, G.B. Forests and climate change: Forcings, feedbacks, and the climate benefits of forests. Science 2008, 320, 1444-1449. [CrossRef]

10. Trenberth, K.E.; Dai, A.; Van der Schrier, G.; Jones, P.D.; Barichivich, J.; Briffa, K.R.; Sheffield, J. Global warming and changes in drought. Nat. Clim. Chang. 2014, 4, 17-22. [CrossRef]

11. Salzer, M.W.; Hughes, M.K.; Bunn, A.G.; Kipfmueller, K.F. Recent unprecedented tree-ring growth in bristlecone pine at the highest elevations and possible causes. Proc. Natl. Acad. Sci. USA 2009, 106, 20348-20353. [CrossRef] [PubMed] 
12. Zhang, J.; Huang, S.; He, F. Half-century evidence from western Canada shows forest dynamics are primarily driven by competition followed by climate. Proc. Natl. Acad. Sci. USA 2015, 112, 4009-4014. [CrossRef] [PubMed]

13. Gómez-Aparicio, L.; García-Valdés, R.; Ruíz-Benito, P.; Zavala, M.A. Disentangling the relative importance of climate, size and competition on tree growth in Iberian forests: Implications for forest management under global change. Glob. Chang Biol. 2011, 17, 2400-2414. [CrossRef]

14. Jump, A.S.; Hunt, J.M.; Peñuelas, J. Rapid climate change-related growth decline at the southern range edge of Fagus sylvatica. Glob. Chang. Biol. 2006, 12, 2163-2174. [CrossRef]

15. Wang, W.; Jia, M.; Wang, G.; Zhu, W.; McDowell, N.G. Rapid warming forces contrasting growth trends of subalpine fir (Abies fabri) at higher- and lower-elevations in the eastern Tibetan plateau. For. Ecol. Manage. 2017, 402, 135-144. [CrossRef]

16. Huo, Y.; Gou, X.; Liu, W.; Li, J.; Zhang, F.; Fang, K. Climate-growth relationships of schrenk spruce (Picea schrenkiana) along an altitudinal gradient in the western Tianshan mountains, Northwest China. Trees 2017, 31, 429-439. [CrossRef]

17. Hasenauer, H. Dimensional relationships of open-grown trees in Austria. For. Ecol. Manage. 1997, 96, 197-206. [CrossRef]

18. Maestre, F.T.; Valladares, F.; Reynolds, J.F. Is the change of plant-plant interactions with abiotic stress predictable? A meta-analysis of field results in arid environments. J. Ecol. 2005, 93, 748-757. [CrossRef]

19. Poulter, B.; Frank, D.; Ciais, P.; Myneni, R.B.; Andela, N.; Bi, J.; Broquet, G.; Canadell, J.G.; Chevallier, F.; Liu, Y.Y.; et al. Contribution of semi-arid ecosystems to interannual variability of the global carbon cycle. Nature 2014, 509, 600-603. [CrossRef]

20. He, Z.; Zhao, W.; Liu, H.; Tang, Z. Effect of forest on annual water yield in the mountains of an arid inland river basin: A case study in the pailugou catchment on northwestern china's qilian mountains. Hydrol. Process. 2012, 26, 613-621. [CrossRef]

21. Zhang, L.; Yu, P.; Wang, Y.; Wang, S.; Liu, X.; Jin, M.; Zhang, X. Altitudinal changes in structure of middle-aged picea crassifolia forests on the northern slope of the qilian mountains. For. Res. 2015, 28, 557-564.

22. Sun, F.; Lü, Y.; Wang, J.; Hu, J.; Fu, B. Soil moisture dynamics of typical ecosystems in response to precipitation: A monitoring-based analysis of hydrological service in the qilian mountains. Catena 2015, 129, 63-75. [CrossRef]

23. Reineke, L.H. Perfecting a stand-density index for even-aged forests. J. Agric. Res. 1933, 46, 627-638.

24. Holmes, R.L. Computer-assisted quality control in tree-ring dating and measurement. Tree Ring Bull. 1983, 43, 69-78.

25. Wigley, T.M.; Briffa, K.R.; Jones, P.D. On the average value of correlated time series, with applications in dendroclimatology and hydrometeorology. J. Clim. Appl. Meteorol. 1984, 23, 201-213. [CrossRef]

26. Lévesque, M.; Saurer, M.; Siegwolf, R.; Eilmann, B.; Brang, P.; Bugmann, H.; Rigling, A.J.G. Drought response of five conifer species under contrasting water availability suggests high vulnerability of Norway spruce and European larch. Glob. Chang. Biol. 2013, 19, 3184-3199. [CrossRef]

27. Wang, J.; Wang, Y.; Li, X.; Jing, W.; Ge, S. Water situation and runoff production in the pailougou basin of qilian mountains. J. Glaciol. Geocryol. 2006, 28, 62-69, (In Chinese with English abstract).

28. Harris, I.; Jones, P.D.; Osborn, T.J.; Lister, D.H. Updated high-resolution grids of monthly climatic observations-The cru ts3. 10 dataset. Int. J. Climatol. 2014, 34, 623-642. [CrossRef]

29. Nowacki, G.J.; Abrams, M.D. Radial-growth averaging criteria for reconstructing disturbance histories from presettlement-origin oaks. Ecol. Monogr. 1997, 67, 225-249. [CrossRef]

30. Wu, X.; Liu, H.; He, L.; Qi, Z.; Anenkhonov, O.A.; Korolyuk, A.Y.; Yu, Y.; Guo, D. Stand-total tree-ring measurements and forest inventory documented climate-induced forest dynamics in the semi-arid Altai mountains. Ecol. Indic. 2014, 36, 231-241. [CrossRef]

31. Pederson, N.; Varner, J.M., III; Palik, B.J. Canopy disturbance and tree recruitment over two centuries in a managed longleaf pine landscape. For. Ecol. Manage. 2008, 254, 85-95. [CrossRef]

32. Coomes, D.A.; Allen, R.B. Effects of size, competition and altitude on tree growth. J. Ecol. 2007, 95, $1084-1097$. [CrossRef]

33. Dulamsuren, C.; Hauck, M.; Kopp, G.; Ruff, M.; Leuschner, C. European beech responds to climate change with growth decline at lower, and growth increase at higher elevations in the center of its distribution range (sw Germany). Trees 2016, 31, 673-686. [CrossRef] 
34. Lyu, L.; Suvanto, S.; Nöjd, P.; Henttonen, H.M.; Mäkinen, H.; Zhang, Q.B. Tree growth and its climate signal along latitudinal and altitudinal gradients: Comparison of tree rings between Finland and the Tibetan plateau. Biogeosciences 2017, 14, 3083-3095. [CrossRef]

35. Körner, C. Paradigm shift in plant growth control. Curr. Opin. Plant Biol. 2015, 25, 107-114. [CrossRef]

36. Körner, C.; Paulsen, J. A world-wide study of high altitude treeline temperatures. J. Biogeogr. 2004, 31, 713-732. [CrossRef]

37. Liang, E.; Camarero, J.J. Threshold-dependent and non-linear associations between temperature and tree growth at and below the alpine treeline. Trees 2017, 32, 661-662. [CrossRef]

38. Waring, R.H.; Gao, L. Recent reduction in the frequency of frost accounts for most of the increased growth of a high elevation spruce forest in northwestern china. Trees 2016, 30, 1225-1236. [CrossRef]

39. DeLucia, E.H.; Smith, W.K. Air and soil temperature limitations on photosynthesis in Engelmann spruce during summer. Can. J. For. Res. 1987, 17, 527-533. [CrossRef]

40. González de Andrés, E.; Camarero, J.J.; Blanco, J.A.; Imbert, J.B.; Lo, Y.H.; Sangüesa-Barreda, G.; Castillo, F.J.; Turnbull, M. Tree-to-tree competition in mixed European beech-scots pine forests has different impacts on growth and water-use efficiency depending on site conditions. J. Ecol. 2018, 106, 59-75. [CrossRef]

41. Ford, K.R.; Breckheimer, I.K.; Franklin, J.F.; Freund, J.A.; Kroiss, S.J.; Larson, A.J.; Theobald, E.J.; HilleRisLambers, J. Competition alters tree growth responses to climate at individual and stand scales. Can. J. For. Res. 2017, 47, 53-62. [CrossRef]

42. Lechuga, V.; Carraro, V.; Vinegla, B.; Carreira, J.A.; Linares, J.C. Managing drought-sensitive forests under global change. Low competition enhances long-term growth and water uptake in abies pinsapo. For. Ecol. Manage. 2017, 406, 72-82. [CrossRef]

43. Wang, B.; Chen, T.; Xu, G.; Wu, M.; Zhang, G.; Li, C.; Wu, G. Anthropogenic-management could mitigate declines in growth and survival of Qinghai spruce (Picea crassifolia) in the east qilian mountains, northeast Tibetan plateau. Agric. Meteorol. 2018, 250, 118-126. [CrossRef]

44. Primicia, I.; Camarero, J.J.; Janda, P.; Čada, V.; Morrissey, R.C.; Trotsiuk, V.; Bače, R.; Teodosiu, M.; Svoboda, M.J.F.E. Management. Age, competition, disturbance and elevation effects on tree and stand growth response of primary Picea abies forest to climate. For. Ecol. Manage. 2015, 354, 77-86. [CrossRef]

45. Sánchez-Salguero, R.; Linares, J.C.; Camarero, J.J.; Madrigal-González, J.; Hevia, A.; Sánchez-Miranda, Á.; Ballesteros-Cánovas, J.A.; Alfaro-Sánchez, R.; García-Cervigón, A.I.; Bigler, C.; et al. Disentangling the effects of competition and climate on individual tree growth: A retrospective and dynamic approach in scots pine. For. Ecol. Manage. 2015, 358, 12-25. [CrossRef]

46. Wang, Y.; Pederson, N.; Ellison, A.M.; Buckley, H.L.; Case, B.S.; Liang, E.; Julio Camarero, J. Increased stem density and competition may diminish the positive effects of warming at alpine treeline. Ecology 2016, 97, 1668-1679. [CrossRef]

47. Linares, J.C.; Camarero, J.J.; Carreira, J.A. Competition modulates the adaptation capacity of forests to climatic stress: Insights from recent growth decline and death in relict stands of the mediterranean fir abies pinsapo. J. Ecol. 2010, 98, 592-603. [CrossRef]

48. Aldea, J.; Bravo, F.; Bravo-Oviedo, A.; Ruiz-Peinado, R.; Rodríguez, F.; Del Rio, M. Thinning enhances the species-specific radial increment response to drought in mediterranean pine-oak stands. Agric. Meteorol. 2017, 237, 371-383. [CrossRef]

49. Magruder, M.; Chhin, S.; Palik, B.; Bradford, J.B. Thinning increases climatic resilience of red pine. Can. J. For. Res. 2013, 43, 878-889. [CrossRef]

50. Wang, B.; Chen, T.; Wu, G.; Xu, G.; Zhang, Y.; Gao, H.; Zhang, Y.; Feng, Q. Qinghai spruce (Picea crassifolia) growth-climate response between lower and upper elevation gradient limits: A case study along a consistent slope in the mid-qilian mountains region. Environ. Earth Sci. 2016, 75, 236. [CrossRef]

51. Ek, A.R.; Dudek, A. Development of Individual Tree Based Stand Growth Simulators: Progress and Applications; Collage of Forestry, Department of Forest Resources Staff Paper Series No. 20; University of Minnesota: Minneapolis, MN, USA, 1980.

52. Berger, U.; Hildenbrandt, H. A new approach to spatially explicit modelling of forest dynamics: Spacing, ageing and neighbourhood competition of mangrove trees. Ecol. Model. 2000, 132, 287-302. [CrossRef]

53. Tian, H.; Chen, G.; Liu, M.; Zhang, C.; Sun, G.; Lu, C.; Xu, X.; Ren, W.; Pan, S.; Chappelka, A. Model estimates of net primary productivity, evapotranspiration, and water use efficiency in the terrestrial ecosystems of the southern united states during 1895-2007. For. Ecol. Manage. 2010, 259, 1311-1327. [CrossRef] 
54. Tian, H.; Lu, C.; Chen, G.; Xu, X.; Liu, M.; Ren, W.; Tao, B.; Sun, G.; Pan, S.; Liu, J. Climate and land use controls over terrestrial water use efficiency in monsoon Asia. Ecohydrology 2011, 4, 322-340. [CrossRef]

55. Cramer, W.; Kicklighter, D.W.; Bondeau, A.; Iii, B.M.; Churkina, G.; Nemry, B.; Ruimy, A.; Schloss, A.L. Comparing global models of terrestrial net primary productivity (npp): Overview and key results. Glob. Chang. Biol. 1999, 5, 1-15. [CrossRef]

56. Kucharik, C.J.; Foley, J.A.; Delire, C.; Fisher, V.A.; Coe, M.T.; Lenters, J.D.; Young-Molling, C.; Ramankutty, N.; Norman, J.M.; Gower, S.T. Testing the performance of a dynamic global ecosystem model: Water balance, carbon balance, and vegetation structure. Glob. Ecol. Biogeogr. 2000, 14, 795-825. [CrossRef]

57. Thum, T.; MacBean, N.; Peylin, P.; Bacour, C.; Santaren, D.; Longdoz, B.; Loustau, D.; Ciais, P. The potential benefit of using forest biomass data in addition to carbon and water flux measurements to constrain ecosystem model parameters: Case studies at two temperate forest sites. Agric. Meteorol. 2017, 234, 48-65. [CrossRef]

58. Clark, J.S.; Bell, D.M.; Hersh, M.H.; Nichols, L. Climate change vulnerability of forest biodiversity: Climate and competition tracking of demographic rates. Glob. Chang. Biol. 2011, 17, 1834-1849. [CrossRef]

59. Collalti, A.; Trotta, C.; Keenan, T.F.; Ibrom, A.; Bond-Lamberty, B.; Grote, R.; Vicca, S.; Reyer, C.P.; Migliavacca, M.; Veroustraete, F. Thinning can reduce losses in carbon use efficiency and carbon stocks in managed forests under warmer climate. JAMES 2018, 10, 2427-2452. [CrossRef]

60. Park, C.E.; Jeong, S.J.; Joshi, M.; Osborn, T.J.; Ho, C.H.; Piao, S.; Chen, D.; Liu, J.; Yang, H.; Park, H.; et al. Keeping global warming within $1.5^{\circ} \mathrm{C}$ constrains emergence of aridification. Nat. Clim. Chang. 2018, 8, 70-74. [CrossRef]

(C) 2019 by the authors. Licensee MDPI, Basel, Switzerland. This article is an open access article distributed under the terms and conditions of the Creative Commons Attribution (CC BY) license (http://creativecommons.org/licenses/by/4.0/). 